\title{
Konativní dimenze environmentální gramotnosti českých a slovenských žáků 2. stupně zš
}

\section{Silvie Svobodová}

\section{Envigogika 13 (2) - Recenzované články/ Reviewed Papers}

Publikováno / Published 12. 12. 2018

DOI : $\underline{10.14712 / 18023061.578}$

\begin{abstract}
Abstrakt
Článek představuje výsledky komparativní analýzy zaměřené na environmentálně odpovědné jednání, tj. konativní dimenzi environmentální gramotnosti, českých $(\mathrm{N}=344)$ a slovenských $(\mathrm{N}=92)$ žáků 2 . stupně ZŠ. $V$ rámci studie byla použita dílčí škála komplexního výzkumného nástroje Middle School Environmental Literacy Survey (MSELS) zjišt́ující environmentálně odpovědné jednání. Uvedený nástroj nebyl v obou zemích dosud aplikován. Na základě analýzy výsledků byl identifikován signifikantní vliv pohlaví, věku, ročníku a volnočasových aktivit na environmentálně odpovědné jednání žáků, přičemž se mezi českými a slovenskými žáky neprojevil statisticky významný rozdíl.
\end{abstract}

\section{Klíčová slova}

Environmentálně odpovědné jednání; MSELS; ČR; Slovensko

\begin{abstract}
The article presents the results of a comparative analysis focused on responsible environmental behavior (REB), i.e. the conative dimension of environmental literacy, Czech ( $N$ $=344)$ and Slovak $(\mathrm{N}=92)$ pupils of primary school. Within the study, a comprehensive Middle School Environmental Literacy Survey (MSELS) was used, which has not yet been applied in both countries. Responsible environmental behavior is identified through a subscale of MSELS which is oriented to REB. Based on the analysis of the results, the significant influence of gender, age, year and free time activities on the responsible environmental behavior of pupils was identified, with no statistically significant difference between Czech and Slovak pupils.
\end{abstract}

\section{Key words}

Responsible environmental behavior; MSELS; CR; Slovakia 


\section{Úvod}

Environmentálně odpovědné jednání (EOJ) reprezentuje konativní složku environmentální gramotnosti, konceptu poprvé vymezeného v 60. letech 20. století, který lze dnes považovat za stěžejní cíl environmentální výchovy souhrnně pojímající její dílčí aspekty (Hungerford \& Volk, 1990; Roth, 1992). Aktuální sofistikovaná definice představuje široké multidimenzionální pojetí environmentální gramotnosti, které Ize shrnout do tří dimenzí, a to kognitivní, afektivní a konativní (Hollweg et al., 2011; Daniš, 2013). Uvedené vymezení pochází z dílny Severoamerické asociace pro environmentální vzdělávání (NAAEE) a je výsledkem několikaleté diskuse $v$ týmu odborníků z oblasti environmentálního vzdělávání (NAAEE, 2010). Konativní dimenze je zde vnímána jako realizace záměrného či obvyklého jednání směřujícího $\mathrm{k}$ vyřešení aktuálních problémů a předcházení novým, a to individuálně či jako člen skupiny (Daniš; 2013).

Výzkumy zaměřené na konativní dimenzi, zvláště u řešené cílové skupiny, jsou u nás i v zahraniční spiše výjimkou. Většinou jsou součástí komplexnějších studií (např. Schovajsová, 2010; McBeth \& Volk, 2010; McBeth et al., 2011; Král', 2013; Stevenson et al., 2014; Krajhanzl \& Skalík, 2015). Mnohá šetření se soustředila na detekování prediktorů a determinantů environmentálně odpovědného jednání (např. Hines et al., 1987; Hungerford \& Volk, 1990; Zelezny, 1999; Bamberg \& Möser, 2007; Krajhanzl, 2010). Schovajsová (2010) např́iklad zjistila, že environmentální profilace školy jednání žáků neovlivňuje významným způsobem a slabý signifikantní vztah prokázala pouze mezi dimenzemi konativní a afektivní, stejně jako Hromádka (2010). McBeth \& Volk (2010), McBeth et al. (2011) a Stevenson et al. (2014) zase identifikovali statisticky významný vliv věku, resp. ročníku, a pohlaví. Zelezny (1999) zaznamenala vliv pohlaví a zásadní vztah mezi formou realizace environmentální výchovy a jednáním žáků. K významným prediktorům řadí Krajhanzl (2010) vztah $\mathrm{k}$ prrírodě, naopak proenvironmentální postoje nepovažuje za jednoznačné prediktory EOJ (Krajhanzl \& Skalík, 2015).

Middle School Environmental Literacy Survey (MSELS) (McBeth et al., 2008) představuje nástroj pokrývající všechny dimenze environmentální gramotnosti vhodný pro žáky 2. stupně Zš. Sestává z několika škál o celkovém počtu 75 položek, zaměřených na environmentální znalosti (environmental knowledge), proenvironmentální postoje, senzitivitu, vztah k životnímu prostředí (environmental affect), dovednosti $k$ analýze a následnému efektivnímu řešení environmentálních problémů, resp. environmentálně odpovědnému jednání (environmental behavior). Nástroj byl opakovaně verifikován, zejména ve Spojených státech amerických (McBeth et al., 2008, 2011; Stevenson et al., 2013; Stevenson et al., 2014), ale také např́klad v rámci testování řeckých studentů (Nastoulas et al., 2017). Naopak v České republice ani na Slovensku nebyl doposud jako celek aplikován. $\vee$ českém prostředí byla použita pouze subškála pro zjištování environmentálních znalostí, a to jako součást dotazníků vlastní konstrukce (Schovajsová, 2010; Činčera, 2013; Svobodová, 2017).

S využitím uvedené škály jednání, resp. její modifikované verze (viz Příloha 1), byla u českých a slovenských žáků 2. stupně ZŠ zjištóvána konativní dimenze environmentální gramotnosti (EOJ) a identifikována významnost vlivu vybraných proměnných (pohlaví, věk, ročník a volnočasové aktivity) na její úroveň včetně komparace výsledků mezi oběma státy. Získaná data a vyvozené výsledky vykazovaly zajímavý charakter, který si zaslouží zvláštní pozornost a vlastní detailní rozbor. 


\section{Metodologie}

Šetření se zúčastnily tři základní školy v ČR $(N=344), 182$ dívek a 162 chlapců, a jedna na Slovensku ( $N=92)$, 44 dívek a 48 chlapců. $V$ ČR byly zařazeny jedna vesnická a dvě městské školy, z toho jedna malá rodinného typu. Na Slovensku se jednalo o městkou církevní školu. Respondenty byli žáci 6 . až 9 . ročníků, celkový počet činil $N=436$, a to 226 dívek a 210 chlapců.

Segment jednání nástroje MSELS představuje kvantitativní škálu složenou z 12 položek, kdy míru souhlasu vyjadřují respondenti na pětibodové Likertově stupnici (Chytrý \& Kroufek, 2017). Odpovědi jsou bodovány hodnotami 5 (souhlasím) až 1 (nesouhlasím). Položky odklánějící se od pozitivně environmentálního pojetí jsou bodovány reverzně. Úvodní část dotazníku je zaměřena na respondentův background, tj. testované proměnné (věk, ročník, pohlaví a volnočasová aktivita).

Reliabilita škály, tj. vnitřní konzistence škály, byla zjišť́ována prostřednictvím výpočtu koeficientu Cronbachova alfa. Vliv proměnných byl následně analyzován s použitím MannWhitneyova U testu u pohlaví a Kruskal-Wallisovy ANOVy včetně post hoc analýzy u dalších proměnných.

\section{Výsledky}

Reliabilita škály jednání dosahovala přijatelných hodnot $(a=0,75)$. Její validitu potvrzuje opakovaná úspěšná verifikace škály jako dílčí složky nástroje MSELS, a to zejména v rámci amerických výzkumů (McBeth \& Volk, 2010; McBeth et al., 2011; Stevenson et al., 2014).

U všech testovaných proměnných byl prokázán signifikantní vliv na EOJ. $V$ prípadě pohlaví byly zjištěny vyšší hodnoty u dívek $(p<0,001)$. Co se týče věku, klesají naměřené hodnoty s narůstajícím věkem, resp. od 12 . do 14. roku, poté dochází k mírnému vzestupu (viz Graf 1). Následná post hoc analýza prokázala statisticky významný rozdíl mezi 12. a 14. rokem $(p<0,001)$. Obdobná zjištění byla zaznamenána rovněž u proměnné ročník $(p<$ $0,001)$. S vyšším ročníkem výsledné hodnoty klesaly. 


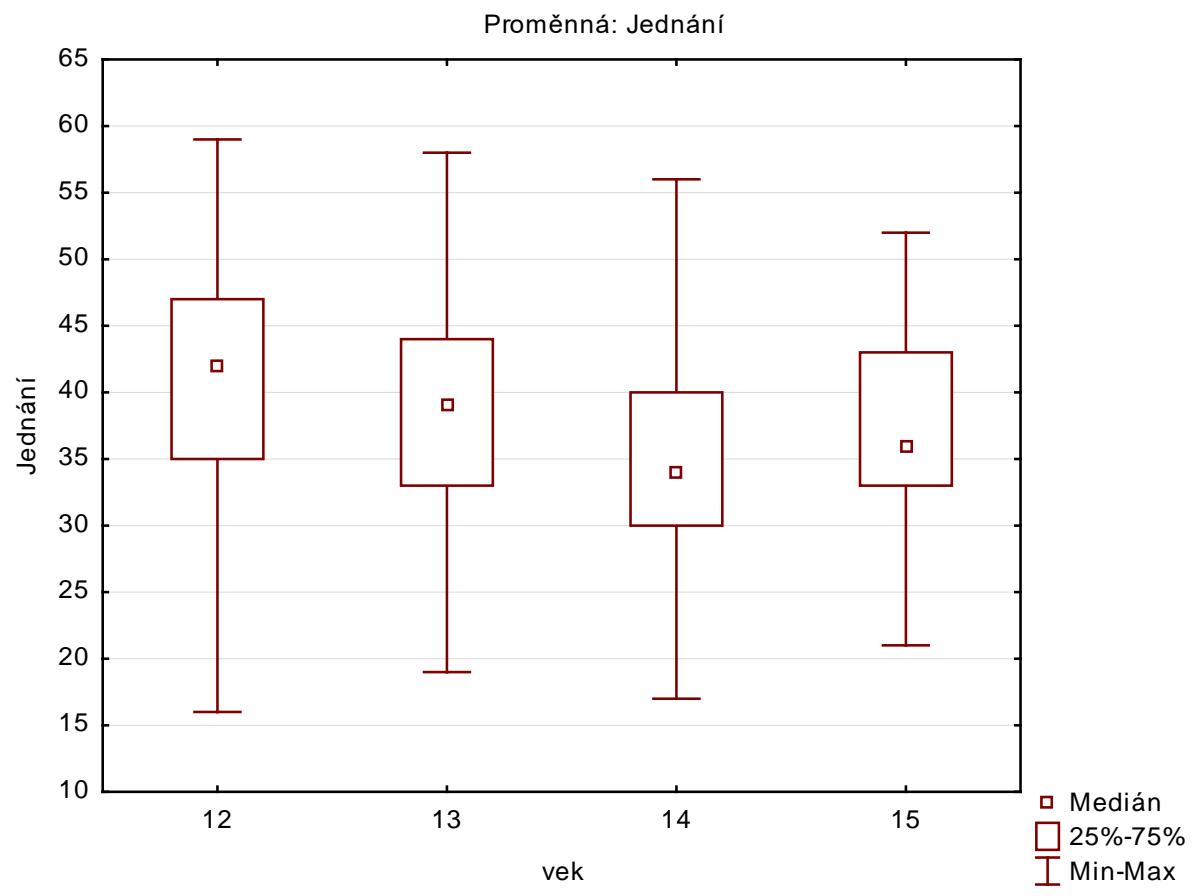

Graf 1: Vztah mezi hodnotami škály jednání a proměnnou věk

Při následné post hoc analýze se nejvýraznější signifikantní rozdíly projevily u 6. a 9. ročníku. Oba ročníky se významně lišily od dalších dvou, šestý od 8. a 9. ročníku a devátý od 6. a 7. ročníku (viz Tabulka 1).

Tabulka 1: Vícenásobné porovnání p hodnot nezávislé proměnné ročník

\begin{tabular}{|c|c|c|c|c|}
\hline \multirow{2}{*}{$\begin{array}{l}\text { Závislá pro- } \\
\text { měnná jednání }\end{array}$} & \multicolumn{4}{|c|}{ Kruskal-Wallisův test: $\mathrm{H}=32,97157 ; p<0,001$} \\
\hline & 6. ročník & 7. ročník & 8. ročník & 9. ročník \\
\hline 6. ročník & & 1,000000 & 0,004710 & 0,000001 \\
\hline 7. ročník & 1,000000 & & 0,145530 & 0,000399 \\
\hline 8. ročník & 0,004710 & 0,145530 & & 0,915178 \\
\hline 9. ročník & 0,000001 & 0,000399 & 0,915178 & \\
\hline
\end{tabular}

Zvýrazněné hodnoty jsou statisticky významné na hladině významnosti $p<0,05$ 
V případě volnočasových aktivit $(p<0,001)$ se projevil nejvýznamnější vliv na EOJ u pobytu v př́rodě oproti trávení volného času u počítače (viz Graf 2). Mezi těmito aktivitami byl také prokázán signifikantní rozdíl ( $p<0,001$ ), přičemž se hodnoty respondentů, kteří preferovali počítač, významně lišily od ostatních volnočasových aktivit kromě aktivity jinak.

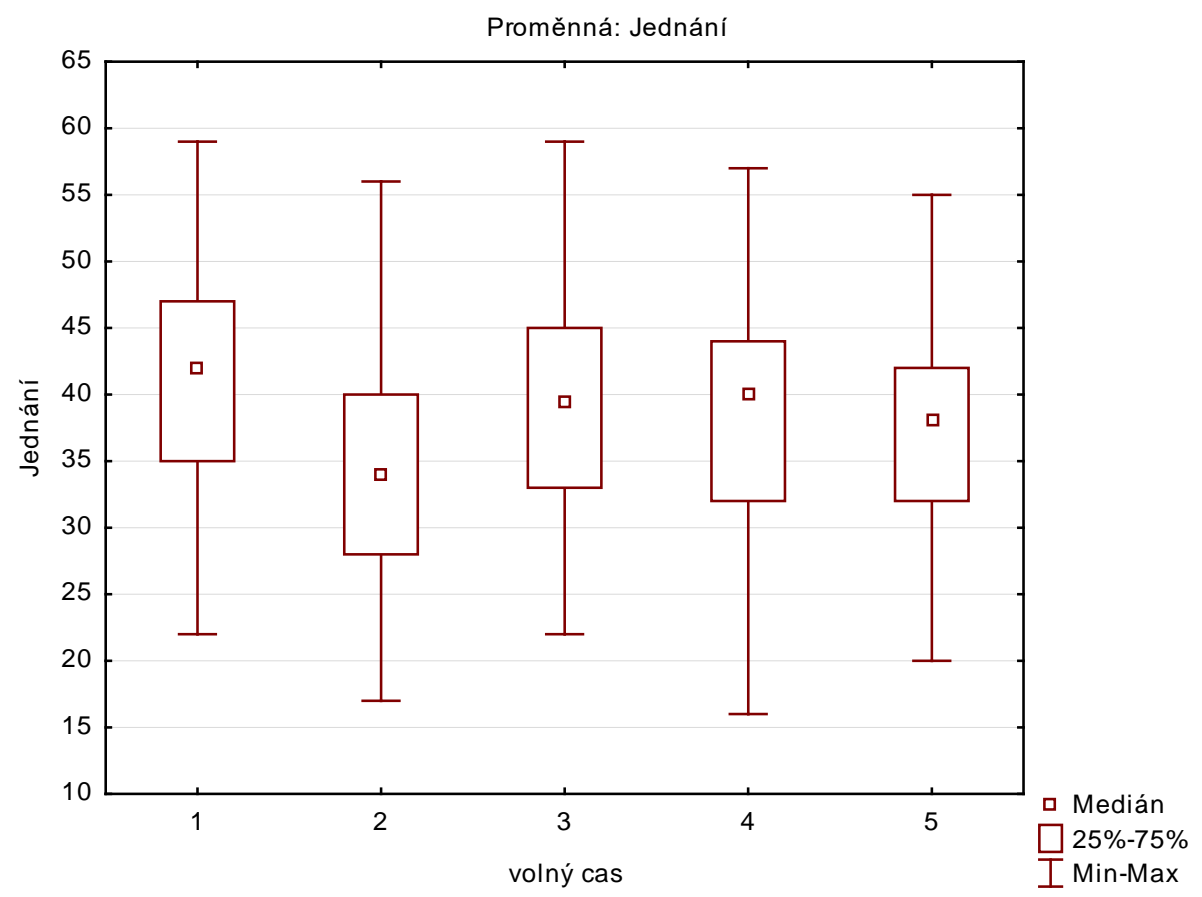

1-pobyt v př́rodě, 2-počítač, 3-zájmová aktivita, 4-sport, 5-jinak

Graf 2: Vztah mezi hodnotami škály jednání a proměnnou volnočasová aktivita

Komparativní analýza ukázala jednoznačné rozdíly v závislosti EOJ na pohlaví mezi ČR a Slovenskem $(p=0,03)$. Dívky z České republiky dosahovaly mírně vyšších hodnot než dívky ze Slovenska, naopak lepší výsledky environmentálně odpovědného jednání se projevily u slovenských chlapců vůči českým (viz Graf 3). 


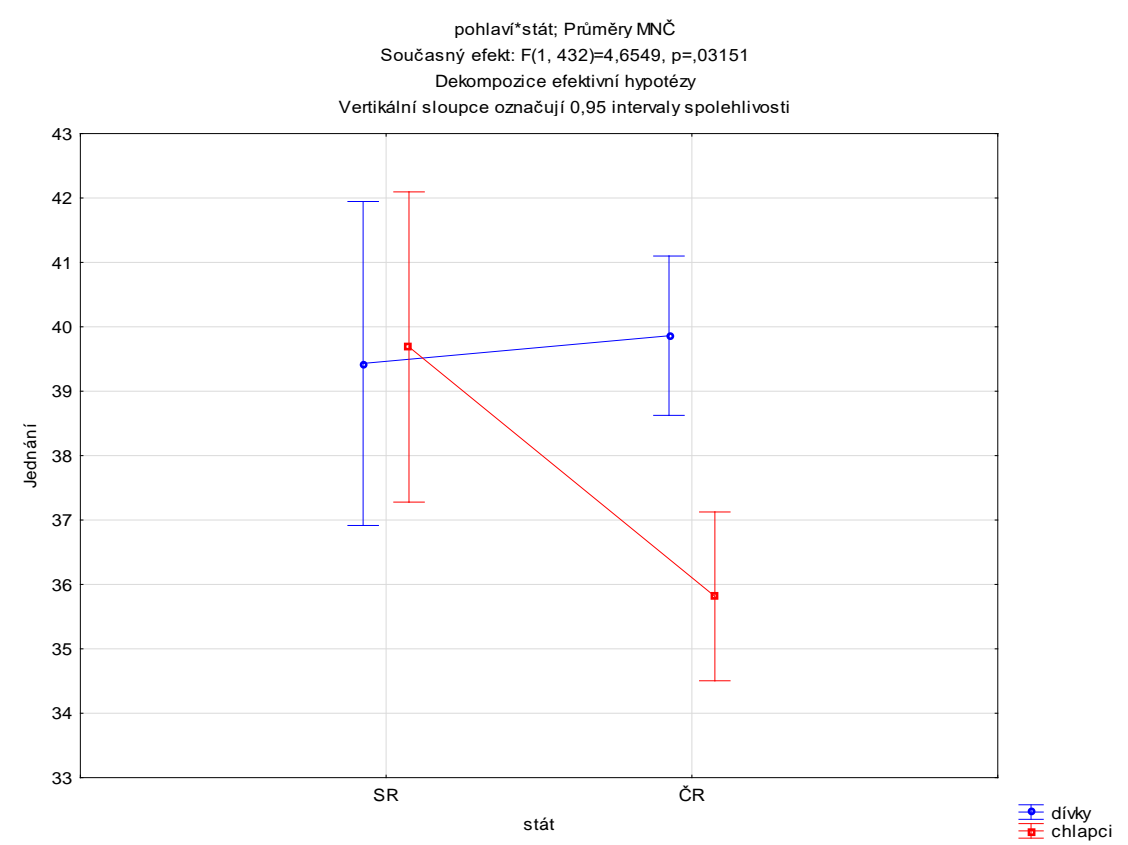

Graf 3: Vztah mezi hodnotami škály jednání a proměnnou pohlaví u obou států

\section{Diskuse}

Dílčí škálu jednání nástroje MSELS zaměřenou na testování EOJ, tj. konativní dimenzi environmentální gramotnosti, Ize z hlediska reliability, kdy koeficient Cronbachovy alfy dosahoval přijatelné hodnoty $(a=0,75)$, považovat za použitelnou (Tavakol \& Dennick, 2011).

Všechny testované proměnné (pohlaví, věk, ročník a volnočasová aktivita) se ve vztahu k EOJ projevily jako zásadní. Vyšší hodnoty environmentálně odpovědného jednání byly zaznamenány u dívek. Shodná zjištění učinili u jiné demografické skupiny např. Kroufek (2016) a Kroufek et al. (2015). Jindy se naopak vliv pohlaví neprojevil jako signifikantní (např. Ogunbode \& Arnold, 2012; Ogunbode, 2013).

S rostoucím věkem výsledky klesaly, resp. do 14. roku věku, a shodně byla nalezena nepřímá úměra mezi ročníkem a EOJ. Obdobná zjištění zaznamenali u téže cílové skupiny Svobodová \& Kroufek (2016). Negativní korelaci mezi věkem a EOJ nalezli také např. Liefländer \& Bogner, (2014), Bogner et al., (2015) a Svobodová (2017). Naopak u jiných skupin respondentů se většinou projevily opačné tendence (Soukup, 2001; Kroufek, 2016), případně nebyl vztah mezi věkem a EOJ prokázán (Činčera \& Štěpánek, 2007; Matějček \& Bartoš, 2012). Jednu z možných př́čin zodpovědnou za tento trend Ize spatřovat v právě probíhajícím osobnostním vývoji spojeném s dospíváním respondentů. Z volnočasových aktivit Ize v souvislosti s EOJ pokládat za nejvíce pozitivní determinant pobyt v prírodě, a to především ve srovnání s časem tráveným u počítače. Ke stejným výsledkům došli u žáků prvního stupně Kroufek et al. (2016). Shodně prokázal kladný vliv pravidelných aktivit spojených s pobytem v př́rodě na EOJ Kroufek (2016), podobně jako např. Hsu \& Roth (1998). Obdobná zjištění o př́znivém vlivu spojitosti s př́rodou na EOJ zaznamenali rovněž Geng et al. (2015) a Pereira \& Forster (2015). Vztah k přírodě jako významný prediktor environmentálně odpovědného jednání potvrdil také např. Krajhanzl (2010). 
V sérii zahraničních výzkumů s nasazením nástroje MSELS není zjištování vlivu uvedených proměnných věnována stěžejní pozornost. Nicméně se jako významný ukázal věk, resp. ročník. Podobná zjištění jako autorka tohoto článku učinili např. McBeth \& Volk (2010), McBeth et al. (2011), Stevenson et al. (2014).

V rámci národní studie environmentální gramotnosti v USA dosáhli žáci u odhodlání $k$ environmentálně odpovědnému jednání nejnižších hodnot Významné rozdíly byly zjištěny také mezi ročníky, u konativní dimenze prokázali vyšší hladinu mladší žáci (McBeth \& Volk, 2010; McBeth et al., 2011). V prípadě řeckého výzkumu nebyl vliv věku na EOJ prokázán, přičemž v porovnání $s$ výsledky amerického šetření vykazovaly zaznamenané hodnoty jednání nižší úroveň (Nastoulas et al., 2017).

Při komparativní analýze byly identifikovány statisticky významné rozdíly mezi Českou republikou a Slovenskem pouze u pohlaví. Environmentálně odpovědněji jednají české dívky oproti slovenským, naopak u chlapců se jako zodpovědnější projevili slovenští chlapci.

\section{Limity studie}

Limitou prezentované studie je nízký počet respondentů, zejména slovenských, a jejich nenáhodný výběr. Vzhledem $\mathrm{k}$ nereprezentativní povaze zkoumaného vzorku nelze tedy výsledky generalizovat na celou cílovou skupinu. Určitou limitu představuje také aplikovaný nástroj. Nevýhodou dotazníku je především riziko, že respondenti mohou své odpovědi vylepšovat, př́padně mohou být $\mathrm{k}$ uvedenému jednání motivováni, ale nemají možnost je vykonávat. Výzvou je rovněž položka č. 4 zjištujúić nejoblíbenější volnočasovou aktivitu. Korektnější výsledky o významnosti vztahu mezi způsobem, jak respondenti tráví svůj volný čas, a EOJ by mohly poskytnout odpovědi respondentů o četnosti jednotlivých aktivit např. na Likertově škále.

\section{Závěr}

Příspěvek seznamuje s výsledky komparativní analýzy konativní dimenze environmentální gramotnosti, tj. environmentálně odpovědného jednání, českých a slovenských žáků 2. stupně Zš včetně identifikace vlivu demografických proměnných (pohlaví, věk, ročník a volnočasová aktivita) s využitím dílči škály jednání nástroje MSELS. Vzhledem k akceptovatelné hodnotě její reliability $(a=0,75)$ Ize použitou škálu pokládat za aplikovatelnou.

U všech řešených demografických proměnných byl detekován signifikantní vliv na EOJ respondentů. Environmentálně odpovědněji jednají žáci, kteří tráví svůj volný čas přednostně pobytem $v$ prírodě oproti těm, kteří preferují počítač. Obdobně byly lepší výsledky zaznamenány u mladších žáků, hodnoty klesaly s narůstajícím věkem, respektive ročníkem. $\checkmark$ případě pohlaví dosahovaly celkově vyšších hodnot dívky, ovšem komparativní analýza dat českých a slovenských žáků ukázala významné rozdíly. $V$ př́padě dívek bylo zjištěno mírně pozitivnější EOJ v České republice, zatímco u chlapců na Slovensku.

Celkový počet respondentů Ize sice považovat za dostatečný, ovšem zastoupení slovenských žáků je nízké a v nepoměru k českým. Reprezentativnost vzorku také není zcela jednoznačně zajištěna, šetření se zúčastnily pouze základní školy, bylo by vhodné zařadit také odpovídající trrídy víceletých gymnázií. Interpretované výsledky nelze tedy generalizovat na celou cílovou skupinu $v$ obou státech. Poskytly však zajímavá zjištění o možných determinantech environmentálně odpovědného jednání. 
Podobná šetření orientovaná na environmentální gramotnost žáků 2. stupně Zš zasazená do širšího kontextu sociokulturní a edukační reality včetně komparace s jinými státy by měla tvořit nezbytnou součást komplexnějších výzkumů zaměřených na environmentální edukaci.

\section{Literatura}

- Bamberg, S. \& Möser, G. (2007). Twenty years after Hines, Hungerford, and Tomera: A new meta-analysis of psycho-social determinants of pro-environmental behaviour. Journal of Environmental Psychology, 27(1), 14-25. doi: 10.1016/j.jenvp.2006.12.002

- Bogner, F. X., Johnson, B., Buxner, S. \& Felix, L. (2015). The 2-MEV model: Constancy of adolescent environmental values within an 8year time frame. International J ournal of Science Education, 37(12), 1938-1952. doi: $10.1080 / 09500693.2015 .1058988$

- Činčera, J. \& Štěpánek, P. (2007). Výzkum ekologické gramotnosti studentů středních odborných škol. Envigogika, 2(1). doi: 10.14712/18023061.12

- Činčera, J. (2013). Metodika pro hodnocení environmentální výchovy pro starší školní věk a střední školy. Envigogika, 8(5). doi: 10.14712/18023061.414

- Daniš, P. (2013). Nové vymezení environmentální gramotnosti a návrh na její mezinárodní testování v PISA 2015. Envigogika, 8(3). doi: 10.14712/18023061.385

- Geng, L., Xu, J., Ye, L., Zhou, W. \& Zhou, K. (2015). Connections with Nature and Environmental Behaviors. PloS One, 10(5). doi: 10.1371/journal.pone.012724

- Hines, J. M., Hungerford, H. R. \& Tomera, A. N. (1987). Analysis and synthesis of research and responsible environmental behavior: A meta analysis. Journal of Environmental Education, 18(2), 1-8. doi: 10.1080/00958964.1987.9943482

- Hollweg, K. S. Taylor, J. R., Bybee, R. W., Marcinkowski, T. J., McBeth, W. C. \& Zoido, P. (2011). Developing a framevork for assessing environmental literacy. Washington, DC: North American Association for Environmental Education.

- Hromádka, Z. (2010). Životní prostředí ve vědomostech, postojích a jednání žáků druhého stupně základní školy. Disertační práce, Brno: Masarykova univerzita, Pedagogická fakulta, $164 \mathrm{~s}$.

- Hsu, S. J. \& Roth, R. E. (1998). An Assessment of Environmental Literacy and Analysis of Predictors of Responsible Environmental Behaviour Held by Secondary Teachers in the Hualien Area of Taiwan. Environmental Education Research, 4(3), 229249. doi: $10.1080 / 1350462980040301$

- Hungerford, H. R. \& Volk, T. (1990). Changing learner behavior through environmental education. J ournal of Environmental Education, 21(3), 8-22. doi: 10.1080/00958964.1990.10753743

- Chytrý, V. \& Kroufek, R. (2017). Možnosti využití Likertovy škály - základní principy aplikace $v$ pedagogickém výzkumu a demonstrace na příkladu zjištování 
vztahu člověka $k$ př́rodě. Scientia in educatione, 8(1). Retrieved from http://www. scied.cz/index. php/scied/article/view/591

- Krajhanzl, J. (2010). Environmental and proenvironmental behavior. In Řehulka, E. [ed.] School and Helath 21: Health Education: Internatonal Experiences. Brno: Masaryk University, 251-274.

- Krajhanzl, J. \& Skalík, J. (2015). Czech Greenpeace Donors and the Barriers to their Climate-Friendly Household Behaviour. Sociální studia, 12(3), 71-95.

- Král', M. (2013). Environmentálna identita, environmentálne postoje a environmentálne zodpovedné správanie slovenských vysokoškolákov. Osobnost'v kontexte kofnícií, emocionality a motivácií IV, Bratislava, 1-9.

- Kroufek, R., Janovec, J. \& Chytrý, V. (2015). Pre-service primary teachers and their attitudes towards nature. In: Fleischmann, O., Seebauer, R., Zoglowek, H., \& Aleksandrovich, M. [eds.] The Teaching profession: New Challneges - New Identities. Lit Verlag GmbH \& Co. KG, Wien.

- Kroufek, R., Chytrý, V., Janovec, J. \& Brtnová Čepičková, I. (2016). Effect of leisure activities on responsible environmental behaviour of pupils of primary school. ICERI 2016 proceedings. 7451-7456. doi: 10.21125/iceri.2016.0703

- Kroufek, R. (2016). Environmentální gramotnost studentů Učitelství pro 1. stupeň základní školy a možnosti jejího zjišttování. Disertační práce, PF JU, České Budějovice. doi: 10.13140/RG.2.1.3858.0724

- Liefländer, A. K. \& Bogner, F. X. (2014). The effects of children's age and sex on acquiring pro-environmental attitudes through environmental education. The Journal of Environmental Education, 45(2), 105-117. doi:

$10.1080 / 00958964.2013 .875511$

- Matějček, T. \& Bartoš, J. (2012). Environmentální gramotnost učitelů a studentů učitelství. Envigogika, 7(2). doi: 10.14712/18023061.75

- McBeth, W., Hungerford, H., Marcinkowski, T., Volk, T. L. \& Meyers, R. (2008). National Environmental Literacy Assessment Project: Year 1, National Baseline Study of Middle Grades Students Final Research Report. U.S. Environmental Protection Agency.

- McBeth, W. \& Volk, T. L. (2010). The National Environmental Literacy Project: A baseline study of middle grade students in the United States. The Journal of Environmental Education, 41,1,55-67.

- McBeth, W., Hungerford, H., Marcinkowski, T., Volk, T. L. \& Cifranick, K. (2011). The National Environmental Literacy Assessment, Phase Two: Measuring the Effectiveness of North Američan Environmental Education Programs with Respect to the Parameters of Environmental Literacy. NOAA.

- NAAEE (2010). Excellence in Environmental Education: Guidelines for Learning (K12). Washington: NAAEE. $121 \mathrm{~s}$.

- Nastoulas, I., Marini, K. \& Skanavis, C., (2017). Middle School Students Environmental Literacy Assessment in Thessaloniki, Greece. Health and Environment Conference Proceedings. Hamdan Bin Mohammed Smart University, Dubai, 198-209. 
- $\quad$ Ogunbode, Ch. A. \& Arnold, K. (2012). A Study of Environmental Awareness and Attitudes in Ibadan, Nigeria. Human and Ecological Risk Assessment: An International Journal 18 (3): 669-684.

- Ogunbode, Ch. A. (2013). The NEP Scale: Measuring Ecological Attitudes/Worldviews in an African Context. Environment, Development and Sustainability 15 (6): 1477-1494.

- $\quad$ Pereira, M. \& Forster, P. (2015). The Relationship between Connectedness to Nature, Environmental Values and Pro-environmental Behaviours. Reinvention: and International J ournal of Undergraduate Research, 8(2).

- Roth, C. E. (1992). Environmental literacy: Its roots, evolution, and directions in the 1990s. Columbus: ERIC Clearingouse for Science, Mathematics and Environmental Education.

- Schovajsová, J. (2010). Současný stav environmentální výchovy na základních školách - vybrané aspekty environmentální gramotnosti dětí mladšího školního věku. Disertační práce. Olomouc: Univerzita Palackého, Pedagogická fakulta, s. 194.

- Soukup, P. (2001). ISSP - životní prostředí. Sociologický ústav Akademie věd České republiky, Praha. ISBN 80-7330-000-1.

- Stevenson, K. T., Carrier, S. J. \& Peterson, M. N. (2014). Evaluating strategies for inclusion of environmental literacy in the elementary school classroom. Electronic Journal of Science Education, 18(8).

- Svobodová, S. \& Kroufek, R (2016). Environmentální gramotnost žáků 2. stupně v Žatci - výzkumná sonda. Envigogika, 11(2). doi: http://dx.doi.org/10.14712/18023061.514.

- Svobodová, S. (2017). Vliv vybraných proměnných na environmentální gramotnost žáků 2. stupně základní školy. Envigogika, 12(1). https://doi.org/10.14712/18023061.539

- Tavakol, M. \& Dennick, R. (2011). Making sense of Cronbach's alpha. International Journal of Medical Education, 2011(2), 53-55. doi: 10.5116/ijme.4dfb.8dfd

- Zelezny, L. C. (1999). Education Interventions That Improve Environmental Behaviors: A Meta-Analysis. The Journal of Environmental Education, 31(1), 5-14. doi: 10.1080/00958969909598627 


\section{Príloha - dotazník}

\section{Demografické údaje}

1. Věk:

$\square 12$ let $\square 13$ let $\square 14$ let $\square 15$ let a více

2. Ročník:
6. ročník
7. ročník
8. ročník
9. ročník

3. Pohlaví:

$\square$ dívka $\square$ chlapec

4. Volný čas trávišs nejraději:

$\square$ pobytem v prírodě

$\square$ u IT (počítače, mobily, tablety atd.)

$\square$ pravidelnou návštěvou zájmové aktivity, uved' jaké:

$\square$ sportováním

$\square$ jinak, uved' jakým způsobem:

\section{Environmentální jednání (český překlad Svobodová, Kroufek)}

U každé otázky zakroužkuj odpověd', která nejpřesněji vystihuje, co děláš pro přírodu a životní prostředí.

5. Nezajímám se o problémy znečištění
a) souhlasím
b) spíše souhlasím
c) nejsem si jistý
d) spíše nesouhlasím
e) nesouhlasím

6. Mluvím se svými rodiči o tom, jak Ize pomáhat při řešení environmentálních problémů
a) souhlasím
b) spíše souhlasím
c) nejsem si jistý
d) spíše nesouhlasím
e) nesouhlasím

7. Při mytí zubů vypínám vodu, abych s ní více šetrìi
a) souhlasím
b) spíše souhlasím
c) nejsem si jistý
d) spíše nesouhlasím
e) nesou- hlasím

8. Nepotřebuji-li doma svítit, zhasínám, abych šetřil/a energiemi
a) souhlasím
b) spíše souhlasím
c) nejsem si jistý
d) spíše nesouhlasím
e) nesou- hlasím 
9. Požádal/a jsem rodiče, aby nekupovali výrobky ze zvířecích kožešin
a) souhlasím
b) spíše souhlasím
c) nejsem si jistý
d) spíše nesouhlasím
e) nesou- hlasím

10. Požádal/a jsem svou rodinu, aby některé věci používali opakovaně
a) souhlasím
b) spíše souhlasím
c) nejsem si jistý
d) spíše nesouhlasím
e) nesou- hlasím

11. Ptám se i ostatních, co můžu udělat já pro snižování znečištění
a) souhlasím
b) spíše souhlasím
c) nejsem si jistý
d) spíše nesouhlasím
e) nesouhlasím

12. Často si čtu o prírodě a životním prostředí
a) souhlasím
b) spíše souhlasím
c) nejsem si jistý
d) spíše nesouhlasím
e) nesou- hlasím

13. Vodovodní kohoutek nechávám téct pouze tehdy, je-li to nezbytně nutné
a) souhlasím
b) spíše souhlasím
c) nejsem si jistý
d) spíše nesouhlasím
e) nesou- hlasím

14. Dokud se rozhoduji, co si vyndám z lednice, nechávám její dveře zavřené
a) souhlasím
b) spíše souhlasím
c) nejsem si jistý
d) spíše nesouhlasím
e) nesouhlasím

15. Poblí̌ svého domova vyvěšuji ptačí budky nebo krmítka
a) souhlasím
b) spíše souhlasím
c) nejsem si jistý
d) spíše nesouhlasím
e) nesou- hlasím

16. Věci v domácnosti netřídím k jejich recyklování (opakovanému využití)
a) souhlasím
b) spíše souhlasím
c) nejsem si jistý
d) spíše nesouhlasím
e) nesouhlasím 